\title{
Hubungan Durasi Olahraga dengan Durasi Penggunaan Internet dan Tingkat Keparahan Depresi pada Mahasiswa UIN Syarif Hidayatullah Jakarta
}

\section{The Association between Duration of Exercise with Duration of Internet Usage and the Severity of Depression among Syarif Hidayatullah State Islamic University Jakarta Students}

\author{
Amalia Sainsiana ${ }^{1}$, Arian Andhika ${ }^{2}$, Amadea Azzahra ${ }^{3}$, Azmul Asmar ${ }^{4}$, Aninditha \\ Hudiya $^{5}$, Haifa F. Hilmi ${ }^{6}$, Yunita F. Nisa ${ }^{7}$, Isa M. Noor ${ }^{8}$, Laifa A. Hendarmin ${ }^{9 *}$ \\ 1,2,3,4,5,6,9 Fakultas Kedokteran, Universitas Islam Negeri Syarif Hidayatullah Jakarta, Jakarta, Indonesia \\ ${ }^{7}$ Fakultas Psikologi, Universitas Islam Negeri Syarif Hidayatullah Jakarta, Jakarta, Indonesia \\ ${ }^{8}$ RSJ Dr. Soeharto Heerdjan, Jakarta, Indonesia
}

*Corresponding author

Email: laifa@uinjkt.ac.id

\begin{tabular}{|c|c|}
\hline & Abstract \\
\hline $\begin{array}{l}\text { Keyword: } \\
\text { Exercise, } \\
\text { Excessive Internet } \\
\text { Use, } \\
\text { Internet Addiction, } \\
\text { Depression, } \\
\text { Patient Health } \\
\text { Questionnaire-9 } \\
(P H Q-9)\end{array}$ & $\begin{array}{l}\text { Background: Physical exercises provide benefits for everyone. Riset Kesehatan Dasar } \\
2018 \text { shows increased proportion of Indonesian who lack of exercise from } 26.1 \% \text { to } 33.5 \% \text {. } \\
\text { Inadequate exercise can reduce productivity which can lead to excessive internet use and } \\
\text { increasing the severity of depression. Objectives: To know the association between } \\
\text { duration of exercise against duration of internet usage and the severity of depression } \\
\text { amongst Syarif Hidayatullah State Islamic University Jakarta students. Methods: This is a } \\
\text { non-experimental quantitative cross-sectional study on students of State Islamic University } \\
\text { Jakarta using Patient Health Questionnaire-9 instrument, which has been validated by } \\
\text { Confirmatory Factor Analysis method. Data were analysed by (1) descriptive statistics to } \\
\text { obtain respondents general characteristics and the variables, (2) independent sample T- } \\
\text { test to analyze the mean difference between the variables of men and women, (3) linear } \\
\text { regression test to examine the relationship between the variables. Results: From } 704 \\
\text { respondents, we found that } 62.1 \% \text { lacked of exercise, 57.8\% using internet excessively, and } \\
71.3 \% \text { suffering moderate to severe depression. Furthermore, these results were common } \\
\text { in women. There was significant negative association between duration of exercise (p- } \\
\text { value=0.000) and duration of internet usage, significant negative association between } \\
\text { duration of exercise ( } \text {-value=0.000) with the severity of depression, and significant } \\
\text { positive association between duration of internet usage (p-value=0.031) with the severity } \\
\text { of depression. Conclusions: There is a significant association between duration of exercise } \\
\text { with duration of internet usage and the severity of depression amongst Syarif Hidayatullah } \\
\text { State Islamic University Jakarta students. }\end{array}$ \\
\hline
\end{tabular}

Kata kunci :

Olahraga,

Penggunaan

Internet

Berlebihan,

Adiksi Internet,

Depresi,

Patient Health

Questionnaire-9

(PHQ-9)

\begin{abstract}
A B S T R A K
Latar belakang: Olahraga dapat memberikan manfaat bagi semua orang. Riset Kesehatan Dasar 2018 melaporkan kurangnya olahraga pada masyarakat Indonesia meningkat dari $26,1 \%$ menjadi $33,5 \%$. Kurangnya berolahraga dapat menurunkan produktivitas seseorang, sehingga menyebabkan penggunaan internet yang berlebihan hingga meningkatkan tingkat keparahan depresi. Tujuan: Melihat hubungan antara durasi olahraga dengan durasi penggunaan internet dan tingkat keparahan depresi pada mahasiswa UIN Syarif Hidayatullah Jakarta. Metode: Penelitian ini adalah studi kuantitatif non-eksperimen pada mahasiswa UIN Syarif Hidayatullah Jakarta menggunakan instrumen Patient Health Questionnaire-9, yang telah diuji validitas konstruk dengan metode Confirmatory Factor Analysis (CFA). Data dianalisa menggunakan (1) statistik deskriptif untuk mendapatkan karakteristik umum responden dan ketiga variabel, (2) independent sample T-test untuk analisis perbedaan rata-rata ketiga variabel diantara laki-laki dan perempuan, serta (3) uji
\end{abstract}


regresi linear sederhana dan berganda untuk mengkaji hubungan antar variabel penelitian. Hasil: Pada 704 responden penelitian ini, didapatkan sebanyak 62,1\% responden kurang berolahraga, 57,8\% responden menggunakan internet secara berlebihan, dan 71,3\% responden mengalami depresi sedang hingga berat, dimana ketiga variabel tersebut lebih banyak terjadi pada responden perempuan. Selain itu, didapatkan juga hubungan negatif yang signifikan antara durasi olahraga $(p$-value $=0,000)$ dengan durasi penggunaan internet, serta didapatkan hubungan negatif yang signifikan antara durasi olahraga $(p$-value $=0,000)$ dengan tingkat keparahan depresi, dan hubungan positif yang signifikan antara durasi penggunaan internet $(p$-value $=0,031)$ dengan tingkat keparahan depresi. Simpulan: Terdapat hubungan yang signifikan antara durasi olahraga dengan durasi penggunaan internet dan tingkat keparahan depresi pada mahasiswa UIN Syarif Hidayatullah Jakarta.

How To Cite : Sainsiana, A. dkk. 2021. Hubungan Durasi Olahraga dengan Durasi Penggunaan Internet dan Tingkat Keparahan Depresi pada Mahasiswa UIN Syarif Hidayatullah Jakarta. Journal of Islamic Medicine. 5(2),96-105.

http://doi.org/10.18860/jim.v5i2.13186

Copyright () 2021

\section{LATAR BELAKANG}

Olahraga adalah salah satu hal terbaik yang dapat dilakukan setiap orang untuk meningkatkan kesehatan mereka, mengurangi beban penyakit kronis, dan mencegah kematian dini. ${ }^{1}$ Berdasarkan data Riset Kesehatan Dasar (Riskesdas) 2013 dan 2018, prevalensi penyakit tidak menular mengalami kenaikan, kenaikan prevalensi penyakit tidak menular ini berhubungan dengan pola hidup, salah satunya adalah aktivitas fisik, didapatkan juga data proporsi aktivitas fisik yang kurang juga naik dari $26,1 \%$ menjadi $33,5 \%$. $^{2,3}$

Salah satu penyakit yang dapat diakibatkan oleh olahraga yang kurang adalah depresi. Pada Riskesdas 2018 didapatkan peningkatan proporsi gangguan jiwa yang cukup signifikan jika dibandingkan dengan tahun 2013, yaitu naik dari $1,7 \%$ menjadi $7 \% .^{3}$ Penelitian B. Schuch F, et al. (2017) menyatakan bahwa tingkat aktivitas fisik yang lebih tinggi pada seseorang akan mengurangi risiko seseorang tersebut untuk mengalami depresi, dan penelitian Cicek $\mathrm{G}$, et al. (2015) menyatakan bahwa kelompok orang yang aktif secara fisik menunjukkan tingkat yang rendah untuk gejala depresi dan gejalanya jauh berkurang pada orang yang aktif berolahraga melebihi 3 jam dalam seminggu. ${ }^{4,5}$

Selain olahraga dapat meningkatkan kesehatan dan mengurangi beban penyakit, olahraga juga dapat mempengaruhi produktivitas dalam menggunakan internet. Pada penelitian George L (2015), didapatkan bahwa terdapat hubungan antara olahraga dengan penggunaan internet, dimana olahraga dapat membantu remaja untuk menjauhkan diri dari menggunakan internet secara berlebihan. ${ }^{6}$

Penggunaan internet, khususnya media sosial telah meningkat secara dramatis, dari hasil survei di tahun 2017 oleh Kementerian Komunikasi dan Informatika, didapatkan $54,68 \%$ penduduk Indonesia menggunakan internet. $^{7}$ Hal ini dapat mengubah cara seseorang untuk berkomunikasi, bersosialisasi, dan menjalin pertemanan, hingga dapat menyebabkan kesedihan, dan kehilangan minat dalam aktivitas sehari-hari. Pada penelitian sebelumnya, yang dilakukan oleh Masih J, et al. (2019), didapatkan hasil bahwa remaja dengan Internet Addiction Disorder (IAD) yang tinggi, lebih cenderung menderita stres emosional dan mental, serta depresi atau kecemasan sosial. ${ }^{8}$

Dengan adanya dasar bukti yang menjanjikan bahwa olahraga dapat menurunkan keparahan gejala depresi dan meningkatkan produktivitas sehari-sehari, salah satunya dalam menggunakan internet, maka penting untuk meninjau peran, manfaat, dan respon neurobiologis yang mendasari pengaruh olahraga terhadap tingkat keparahan depresi dan penggunaan internet. Penggunaan internet yang berlebihan pun juga dapat menyebabkan terjadinya gejala depresi pada seseorang. ${ }^{4}$ 
Banyaknya mahasiswa yang berada dalam tahap peralihan dari usia remaja ke dewasa, dan World Health Organization (WHO) menyebutkan bahwa pada masa transisi dari usia anak ke remaja hingga dewasa, jumlah aktivitas fisik yang dilakukan cenderung menurun, utamanya pada perempuan, dan perbedaan tersebut berlanjut hingga usia dewasa hingga lansia. ${ }^{1}$

Oleh karena itu diperlukan penelitian lainnya mengenai olahraga yang kurang pada mahasiswa, karena jika mahasiswa dengan olahraga yang kurang semakin bertambah, maka dapat menyebabkan meningkatnya penggunaan internet secara berlebihan dan gejala depresi, ditambah dengan saat ini dimana komposisi pengguna internet di Indonesia berdasarkan usia terbanyak ialah usia 19 hingga 34 tahun, dengan persentase $49,52 \% .^{7}$

UIN Syarif Hidayatullah Jakarta merupakan salah satu universitas keagamaan dibawah Kementerian Agama RI yang berada di Kota Tangerang Selatan, Provinsi Banten yang memiliki total 23.961 mahasiswa. Hingga saat ini bagaimana kondisi aktivitas olahraga, penggunaan internet, dan gejala depresi pada mahasiswa di lingkungan UIN Syarif Hidayatullah Jakarta yang memiliki fakultas agama dan sains sebanyak 12 fakultas, belum diketahui. Oleh karena itu, penelitian ini dilaksanakan.

\section{METODE}

\section{Rancangan dan Responden Penelitian}

Penelitian dengan desain penelitian studi cross-sectional kuantitatif noneksperimen pada mahasiswa UIN Syarif Hidayatullah Jakarta yang sedang menempuh pendidikan strata 1 (S1) ini dilakukan pada bulan Februari hingga Agustus 2020. Teknik pengambilan sampel dilakukan dengan cara convenience sampling. Pengambilan data primer dilakukan pada 750 mahasiswa melalui pengisian kuesioner setelah mendapatkan keterangan lolos kaji etik, 48 mahasiswa masuk ke dalam kriteria eksklusi karena tidak mengisi kuesioner secara lengkap, sehingga yang dianalisis dalam penelitian ini menjadi 704 mahasiswa.

\section{Instrumen Penelitian}

Kuesioner yang digunakan terdiri dari kuesioner semi terstruktur mengenai sosiodemografi, profil umum olahraga dan penggunaan internet yang masing-masing dinilai secara subjektif dengan satu pertanyaan, serta Patient Health Questionnaire (PHQ-9) untuk mengukur tingkat keparahan depresi. PHQ-9 didasarkan langsung pada kriteria diagnostik dalam Diagnostic and Statistical Manual Fourth Edition (DSM-IV) dan International Classification of Diseases (ICD-10), yang terdiri dari sembilan pertanyaan yang fokus pada kriteria diagnostik DSM-IV untuk Major Depressive Disorder (MDD). ${ }^{9}$

\section{Pengolahan Data}

Pada pengukuran PHQ-9 dilakukan uji validitas konstruk dengan metode Confirmatory Factor Analysis (CFA) menggunakan software Mplus 6.1 untuk menguji apakah masing-masing item pertanyaan PHQ-9 dapat mengukur tingkat keparahan depresi, hal ini bertujuan untuk melihat apakah total skor yang dimaksud merupakan skala yang bersifat unidimensional, yaitu skala yang hanya mengukur tingkat keparahan depresi.

Data diolah dengan menggunakan SPSS v25. Karakteristik ketiga variabel responden penelitian dianalisa secara statistik deskriptif. Independent sample T-test digunakan untuk analisis perbedaan rata-rata ketiga variabel penelitian. Untuk menguji hipotesis, penelitian ini menggunakan uji regresi linear sederhana untuk mengkaji hubungan antara durasi olahraga dengan durasi penggunaan internet, serta uji regresi linear berganda untuk mengkaji hubungan durasi olahraga dan durasi penggunaan internet dengan tingkat keparahan depresi.

\section{Etik}

Penelitian ini sudah memenuhi keterangan lolos kaji etik dari Komite Etik Fakultas Kedokteran UIN Syarif Hidayatullah 
Jakarta, dengan nomor surat kaji etik penelitian B-009/F12/KEPK/TL.00/2/202 dan nomor protokol $3674022 \mathrm{P} 111132020022500006$.

\section{HASIL DAN PEMBAHASAN}

\section{Karakteristik Durasi Olahraga Responden Penelitian}

Berdasarkan Physical Activity

Guidelines for Americans, second editions, rekomendasi durasi olahraga dalam seminggu untuk usia dewasa dibagi menjadi 3 , yaitu durasi olahraga kurang bila $<1,25$ jam, cukup bila $1,25-2,5$ jam, dan berlebihan bila $>2,5$ jam. $^{10}$

Pada guideline tersebut, berdasarkan penelitian ilmiah selama bertahun-tahun, dijelaskan bahwa selain intensitas olahraga yang lebih tinggi dan frekuensi olahraga yang lebih besar pada setiap orang, durasi olahraga juga mempengaruhi banyaknya manfaat kesehatan yang didapatkan oleh setiap orang, ${ }^{10}$ dimana semakin lama durasi olahraga maka semakin seseorang tersebut mendapatkan banyak manfaat kesehatan tambahan. Manfaat tambahan yang didapatkan seperti menurunkan resting heart rate, mempercepat pengosongan saluran pencernaan khususnya pada usus halus, meningkatkan metabolisme tubuh, hingga menurunkan risiko depresi dan kecemasan, serta meningkatkan produktivitas seharihari. ${ }^{10,11}$

Dari 704 responden didapatkan $62,1 \%$ $(n=437)$ mahasiswa dengan durasi olahraga kurang, 24,6\% (n=173) dengan durasi olahraga cukup, dan $13,3 \%(\mathrm{n}=94)$ dengan durasi olahraga berlebihan. Ketiga kategorisasi durasi olahraga ini lebih tinggi terjadi pada perempuan dibandingkan lakilaki (tabel 1).

Hasil ini selaras dengan penelitian Wahyudi R, et al. (2015) pada mahasiswa kedokteran tahun pertama Universitas Riau, bahwa 82\% ( $n=136)$ mahasiswa tergolong dalam kategori tidak rutin berolahraga, dan $18 \%(\mathrm{n}=30)$ rutin berolahraga. ${ }^{12}$ Pada penelitian El Ansari W, et al. (2014) juga didapatkan hasil bahwa secara keseluruhan responden mahasiswa perempuan dari 9 universitas di Libya tidak mencapai pedoman tingkat aktivitas fisik yang direkomendasikan. ${ }^{13}$

Untuk hasil independent sample T-test (tabel 1), didapatkan bahwa terdapat perbedaan yang signifikan pada rata-rata durasi olahraga dalam seminggu antara lakilaki dan perempuan, dengan rata-rata durasi olahraga pada laki-laki lebih lama daripada perempuan ( $p$-value uji $\mathrm{T}=0,000 ;$ mean difference $=0,45079)$.

Hasil ini sesuai dengan penelitian Luzak A, et al. (2017), yaitu didapatkan ratarata durasi olahraga pada laki-laki dalam sehari yaitu selama 35 menit, lebih lama daripada rata-rata durasi olahraga pada perempuan dalam sehari, yaitu selama 28 menit. $^{14}$

\section{Karakteristik Durasi Penggunaan Internet Responden Penelitian}

Kategorisasi durasi penggunaan internet dalam sehari berdasarkan DSM-V dibagi menjadi 2, yaitu durasi penggunaan internet dalam batas normal bila $<8$ jam, dan berlebihan bila $\geq 8$ jam. ${ }^{15}$

Pada penelitian ini, 57,8\% $\quad(n=407)$ mahasiswa menggunakan internet berlebihan dan 42,2\% ( $\mathrm{n}=297)$ menggunakan internet dalam batas normal. Kedua kategorisasi durasi penggunaan internet ini lebih tinggi terjadi pada perempuan dibandingkan lakilaki (tabel 1).

Hasil ini tidak jauh berbeda dengan penelitian Rabadi L, et al. (2017) pada 4.388 mahasiswa Jordan University of Science and Technology, bahwa responden terbanyak pada penelitian tersebut adalah responden dengan durasi penggunaan internet selama 46 jam dalam sehari, dilanjutkan dengan responden dengan durasi penggunaan internet selama 7-12 jam dalam sehari. ${ }^{16}$

Berbeda dengan hasil penelitian ini, pada penelitian Kannan B, et al. (2019) terhadap 201 mahasiswa kedokteran dalam rentang usia 18 hingga 25 tahun di Jawaharlal Institute of Postgraduate Medical Education and Research, Puducherry, India, didapatkan prevalensi adiksi internet di antara mahasiswa 
laki-laki secara signifikan lebih tinggi, yaitu $82,8 \%$, daripada perempuan, $17,2 \% .{ }^{17}$

Untuk hasil independent sample T-test (tabel 1), didapatkan bahwa terdapat kecenderungan rata-rata durasi penggunaan internet pada laki-laki lebih rendah daripada perempuan, tetapi berdasarkan hasil statistik belum terdapat perbedaan yang signifikan pada rata-rata durasi penggunaan internet dalam sehari antara laki-laki dan perempuan ( $p$-value uji $\mathrm{T}=0,128 ;$ mean difference $=$ $0,75920)$.

Hasil ini juga berbeda dengan penelitian Vyjayanthi S, et al. (2014) dengan responden 810 mahasiswa, yaitu didapatkan bahwa terdapat perbedaan yang signifikan pada kecanduan internet antara laki-laki dan perempuan, dimana laki-laki memiliki nilai rata-rata yang lebih tinggi untuk adiksi internet daripada perempuan, hal ini dipengaruhi oleh tujuan penggunaan internet yang berbeda pada masing-masing mahasiswa. ${ }^{18}$ Pada penelitian sebelumnya disebutkan bahwa sebagian besar perempuan menggunakan internet untuk media sosial, sedangkan sebagian besar laki-laki menggunakan internet untuk bermain game online, situs dewasa, dan lain-lain. ${ }^{19}$

Perbedaan hasil antara penelitian ini dengan penelitian sebelumnya dapat disebabkan oleh beberapa faktor, seperti perbedaan jumlah responden antara laki-laki dan perempuan, karakteristik responden, tujuan penggunaan internet pada masingmasing responden, dan lain-lain.

\section{Karakteristik Tingkat Keparahan Depresi Responden Penelitian}

Pada umumnya, untuk melihat skor dari PHQ-9, digunakan skor total dari keseluruhan item, yaitu 0 hingga 27 dengan titik potong skor $5,10,15$ dan 20 , sehingga akan didapatkan lima kategori tingkat keparahan depresi. ${ }^{20}$ Namun, pada penelitian ini dilakukan pertimbangan bobot dari masing-masing item, sehingga didapatkan factor score dan T-score untuk menggambarkan skor tingkat keparahan depresi tersebut serta bobot muatan faktor dari setiap item.
Factor score atau $T$-score ini yang akan digunakan sebagai pengganti skor total pada umumnya untuk mengukur tingkat keparahan depresi. Kategorisasi tingkat keparahan depresi sendiri berdasarkan PHQ-9 dibagi menjadi lima, yaitu tidakminimal, ringan, sedang, sedang-berat, dan berat.

Pada uji validitas konstruk PHQ-9 dengan metode CFA, didapatkan model fit dengan data, yang diperoleh setelah dilakukan modifikasi model dengan lima kali membebaskan korelasi antar kesalahan pengukuran pada item-item yang terpilih. Hal ini didasarkan dari 2 nilai Root Mean Square Error of Approximation (RMSEA), yaitu nilai estimate sebesar $0,046(<0,05)$, dan nilai probabilitas RMSEA kurang dari sama dengan 0,05 sebesar 0,702 (>0,05). Maka, PHQ-9 yang digunakan pada penelitian ini bersifat unidimensional, yang berarti setiap item PHQ-9 hanya mengukur satu variabel saja, yaitu tingkat keparahan depresi. Setelah itu, dilihat juga nilai signifikansi pada setiap item, didapatkan bahwa semua item PHQ-9 pada penelitian ini memiliki nilai $\mathrm{T}>1,96$, sehingga semua item ini valid dan dapat digunakan untuk mengukur variabel tingkat keparahan depresi.

Pada penelitian ini sebagian besar mahasiswa, 42,8\% ( $\mathrm{n}=301)$, masuk ke dalam kategori depresi sedang. Sedangkan 22,1\% $(\mathrm{n}=156)$ mahasiswa mengalami depresi sedang-berat, dan 6,4\% ( $\mathrm{n}=45)$ mengalami depresi berat. Kelima kategorisasi tingkat keparahan depresi ini lebih tinggi terjadi pada perempuan dibandingkan laki-laki (tabel 1).

Hasil ini memiliki persentase yang sedikit lebih rendah dari penelitian sebelumnya oleh Peltzer K, et al. (2013) pada 820 mahasiswa Obafemi Awolowo University, Nigeria, dimana pada penelitian tersebut didapatkan bahwa prevalensi untuk depresi sedang-berat 25,2\% dan depresi berat sebesar $7 \% .^{21}$ Prevalensi depresi pada mahasiswa ini dapat disebabkan oleh perubahan gaya hidup yang dapat menyebabkan berbagai macam tekanan, seperti akademik, keuangan, interpersonal, 
dan lain-lain yang terjadi pada mahasiswa ketika mereka masuk ke universitas, sehingga dengan adanya masa transisi ini dapat meningkatkan risiko depresi pada mahasiswa. $^{22}$

Pada penelitian Pearson C, et al. (2013) dengan responden usia 16 hingga diatas 65 tahun juga didapatkan bahwa prevalensi depresi berat lebih banyak terjadi pada wanita, yaitu sebesar 5,8\% dibandingkan pada pria yang sebesar $3,6 \%$. Peningkatan prevalensi depresi ini berkorelasi dengan perubahan hormonal pada wanita, terutama selama masa pubertas, sebelum menstruasi, setelah kehamilan, dan saat peri-menopause, hal ini menunjukkan bahwa fluktuasi hormonal pada wanita dapat menjadi pemicu depresi. ${ }^{23}$

Untuk hasil independent sample T-test (tabel 1), didapatkan bahwa belum terdapat perbedaan yang signifikan pada rata-rata tingkat keparahan depresi antara laki-laki dan perempuan, namun terdapat kecenderungan rata-rata tingkat keparahan depresi pada lakilaki lebih rendah daripada perempuan ( $p$ value uji $\mathrm{T}=0,279 ;$ mean difference $=-$ 0,82132 ).

Hasil ini sesuai dengan penelitian Flesch B, et al. (2020) pada 1.827 mahasiswa yang telah mengisi instrumen PHQ-9, yaitu didapatkan bahwa sebanyak 32\% mahasiswa mengalami depresi, dengan rasio prevalensi pada perempuan lebih tinggi dibandingkan laki-laki. Hal ini disebabkan oleh berbagai faktor risiko, seperti aspek individu, keluarga, dan perilaku, selain itu aspek akademik juga dapat mempengaruhi terjadinya depresi di kalangan mahasiswa. ${ }^{24}$

Hasil perbedaan yang belum signifikan pada penelitian ini dapat disebabkan oleh perbedaan jumlah responden antara laki-laki dan perempuan, faktor risiko depresi lainnya yang dimiliki masing-masing responden antara penelitian ini dan sebelumnya, dan lain-lain. Selain itu untuk menilai tingkat keparahan depresi pada penelitian ini menggunakan $T$-score, dimana dilakukan pertimbangan bobot dari masing-masing item PHQ-9, sedangkan pada penelitianpenelitian sebelumnya menggunakan total skor dari masing-masing item PHQ-9, tanpa mempertimbangkan bobot dari masingmasing item.

\section{Hubungan Karakteristik Durasi Olahraga dengan Durasi Penggunaan Internet}

Hasil analisis uji regresi linear sederhana pada penelitian ini (tabel 2), didapatkan hubungan yang signifikan antara durasi olahraga dalam seminggu terhadap durasi penggunaan internet dalam sehari $\left(\mathrm{R}^{2}=0,041 ; \quad \mathrm{F}_{\text {hitung }}=30,299 ; \quad p\right.$-value uji$\mathrm{F}=0.000$; $\mathrm{t}_{\text {hitung }}=-5,504 ;$-value uji- $\left.\mathrm{t}=0,000\right)$.

Hubungan antara durasi olahraga dengan durasi penggunaan internet ini memiliki arah yang negatif, dimana semakin kurang durasi olahraga dalam seminggu pada mahasiswa, maka akan semakin bertambah durasi penggunaan internet dalam seharinya, begitu juga sebaliknya $(a=11,193 ; b=-1,059$; $t_{\text {hitung }}=-5,504$ ).

Hasil uji regresi linear sederhana ini sesuai dengan penelitian Masih J, Rajkumar R (2019), bahwa berolahraga atau menghabiskan lebih banyak waktu dengan teman-teman dan mengembangkan jejaring sosial yang sehat dapat mengobati IAD, sehingga dapat disimpulkan bahwa dengan berolahraga dapat menurunkan lama waktu menggunakan internet. ${ }^{8}$ Hasil ini juga selaras dengan penelitian Koçak Ç (2019), yaitu terdapat penurunan periode penggunaan internet pada mahasiswa yang rutin berolahraga karena dengan olahraga secara teratur dapat mengurangi tingkat kecanduan internet dan waktu yang dihabiskan untuk menggunakan internet, dan penelitian Sahin M, Lok S (2018) di Konya, Turki pada 100 orang dewasa dari usia 17 tahun ke atas, didapatkan hasil bahwa responden dengan tingkat aktivitas fisik yang rendah lebih banyak menggunakan internet. ${ }^{25,26}$

\section{Hubungan Karakteristik Durasi Olahraga dan Durasi Penggunaan Internet dengan Tingkat Keparahan Depresi}

Hasil analisis uji regresi linear berganda pada penelitian ini (tabel 3), didapatkan hubungan yang signifikan antara durasi olahraga dalam seminggu dan durasi 
penggunaan internet dalam sehari dengan tingkat keparahan depresi $\left(\mathrm{R}^{2}=0,086\right.$; $\mathrm{F}_{\text {hitung }}=33,070 ; p$-value uji-F=0.000; $\mathrm{t}_{\text {hitung } 1}=-$ 7,$236 ; p$-value uji- $\mathrm{t}_{1}=0,000 ; \mathrm{t}_{\text {hitung }}=2,162 ; p$ value uji- $\left.\mathrm{t}_{2}=0,031\right)$.

Hubungan antara durasi olahraga dengan tingkat keparahan depresi memiliki arah yang negatif, dimana semakin kurang durasi olahraga dalam seminggu pada mahasiswa, maka akan semakin berat tingkat keparahan depresinya, begitu juga sebaliknya $\left(\mathrm{a}=51,683 ; \mathrm{b}_{1}=-2,111 ; \mathrm{t}_{\text {hitung } 1}=-7,236\right)$. Untuk hubungan antara durasi penggunaan internet dengan tingkat keparahan depresi memiliki arah yang positif, dimana semakin lama durasi penggunaan internet dalam sehari pada mahasiswa, maka akan semakin berat tingkat keparahan depresinya, begitu juga sebaliknya $\left(\mathrm{a}=51,683 ; \mathrm{b}_{2}=0,121 ; \mathrm{t}_{\text {hitung2 }}=2,162\right)$.

Hasil uji regresi linear berganda ini sesuai dengan penelitian Cicek $\mathrm{G}$, et al. (2015) pada 136 orang dewasa yang jarang berolahraga dan 496 orang dewasa yang aktif berolahraga dari usia 18 hingga 45 tahun, bahwa pada kelompok responden yang aktif secara fisik menunjukkan tingkat yang rendah untuk gejala depresi dan gejalanya jauh berkurang pada orang yang aktif berolahraga 3 jam atau lebih dalam seminggu, hal ini menunjukkan bahwa terdapat hubungan antara durasi olahraga dengan gejala depresi, dimana gejala depresi dapat dikurangi dengan melakukan olahraga secara teratur. ${ }^{5}$ Penelitian B. Schuch F, Stubbs B (2017) juga menjelaskan bahwa tingkat aktivitas fisik yang lebih tinggi pada seseorang akan mengurangi risiko seseorang tersebut untuk mengalami depresi. ${ }^{4}$ Hasil ini juga dijelaskan lebih lanjut pada penelitian B. Murri M, et al. (2019), yaitu olahraga dapat digunakan sebagai pengobatan depresi, olahraga dapat dibandingkan dengan obat antidepresan sebagai pengobatan lini pertama untuk depresi ringan hingga sedang. Olahraga juga telah terbukti memperbaiki gejala depresi bila digunakan sebagai tambahan untuk pengobatan yang efektif dan lebih menghemat biaya. ${ }^{27}$
Sementara itu, hasil uji regresi linear berganda ini juga sesuai dengan penelitian Masih J, Rajkumar R (2019), bahwa penggunaan internet secara obsesif yang mengarah ke IAD ini memiliki implikasi negatif, seperti kesedihan dan kehilangan minat dalam kegiatan sehari-hari. Remaja yang memiliki IAD tinggi, lebih cenderung menderita stres emosional dan mental, serta depresi atau kecemasan sosial. ${ }^{8}$ Hasil ini dijelaskan lebih lanjut pada penelitian Rabadi L, et al. (2017) terhadap 4.388 mahasiswa Jordan University of Science and Technology, bahwa Internet Addiction (IA) mempengaruhi stres, kecemasan, dan depresi secara langsung. Mahasiswa dengan IA lebih tinggi kemungkinannya untuk secara emosional atau mental terserang stres, kecemasan, dan depresi, hal ini dikarenakan rasio mahasiswa yang menghabiskan paling banyak waktu di internet meningkat seiring dengan meningkatnya keparahan depresi. ${ }^{16}$

Penelitian Orsal O, et al. (2019) pada mahasiswa tahun pertama di Eskisehir Osmangazi University (ESOGU) juga menjelaskan bahwa kecanduan internet adalah masalah kesehatan utama di antara mahasiswa tahun pertama yang belajar di ESOGU. Terdapat korelasi positif yang signifikan antara tingkat depresi dan kecanduan internet, sehingga akan sangat diperlukan untuk mengedukasi mahasiswa terkait penggunaan internet yang terkontrol, serta merujuk mahasiswa yang dicurigai mengalami depresi dan kecanduan internet ke pusat lanjutan untuk diagnosis dan pengobatan yang akurat. ${ }^{28}$ 
Tabel 1. Karakteristik Responden Penelitian

\begin{tabular}{lcccc}
\hline \multicolumn{1}{c}{ Karakteristik } & Laki-Laki & Perempuan & Total & P-value uji T \\
\hline Durasi Olahraga & & & & \\
Kurang & $109(15,5 \%)$ & $328(46,6 \%)$ & $437(62,1 \%)$ & 0,000 \\
Cukup & $49(7 \%)$ & $124(17,6 \%)$ & $173(24,6 \%)$ & \\
Berlebihan & $43(6,1 \%)$ & $51(7,2 \%)$ & $94(13,3 \%)$ & 0,128 \\
\hline Durasi Penggunaan Internet & & & & \\
Dalam Batas Normal & $87(12,4 \%)$ & $210(29,8 \%)$ & $297(42,2 \%)$ & \\
Berlebihan & $114(16,2 \%)$ & $293(41,6 \%)$ & $407(57,8 \%)$ & 0,279 \\
Tingkat Keparahan Depresi & & & & \\
Tidak-Minimal & $12(1,7 \%)$ & $33(4,7 \%)$ & $45(6,4 \%)$ & \\
Ringan & $48(6,8 \%)$ & $109(15,5 \%)$ & $301(22,3 \%)$ & \\
Sedang & $90(12,8 \%)$ & $211(30 \%)$ & $156(22,1 \%)$ & \\
Sedang-Berat & $39(5,5 \%)$ & $117(16,6 \%)$ & $45(6,4 \%)$ & \\
Berat & $12(1,7 \%)$ & $33(4,7 \%)$ & & \\
\hline
\end{tabular}

Tabel 2. Hasil Analisis Uji Regresi Linear Sederhana

\begin{tabular}{lccc}
\hline \multicolumn{1}{c}{ Variabel } & Koefisien Regresi & thitung & P-value \\
\hline Konstanta & 11,193 & & \\
Durasi olahraga / minggu & $-1,059$ & $-5,504$ & 0,000 \\
\hline Fhitung $=30,299$ & & & 0,000 \\
\hline $\mathrm{R}^{2}=0,041$ & & & \\
\hline
\end{tabular}

*Dependent Variable: Durasi Penggunaan Internet / hari

Tabel 3. Hasil Analisis Uji Regresi Linear Berganda

\begin{tabular}{lccc}
\hline \multicolumn{1}{c}{ Variabel } & Koefisien Regresi & thitung & P-value \\
\hline Konstanta & 51,683 & & 0,000 \\
Durasi olahraga / minggu & $-2,111$ & $-7,236$ & 0,031 \\
Durasi penggunaan internet/ hari & 0,121 & 2,162 & 0,000 \\
\hline $\mathrm{F}_{\text {hitung }}=33,070$ & & & \\
\hline $\mathrm{R}^{2}=0,086$ & & & \\
\hline
\end{tabular}

*Dependent Variable: $T$-score $P H Q-9$ (Tingkat Keparahan Depresi)

\section{KESIMPULAN}

Berdasarkan penelitian yang telah dilakukan ini, dapat ditarik kesimpulan bahwa sebagian besar mahasiswa UIN Syarif Hidayatullah Jakarta, yaitu lebih dari 50\% responden penelitian kurang berolahraga, menggunakan internet berlebihan, serta mengalami depresi sedang hingga berat, lalu mahasiswa dengan olahraga yang kurang, penggunaan internet berlebihan, dan depresi berat tersebut lebih banyak terjadi pada perempuan dibandingkan laki-laki. Selain itu berdasarkan hasil uji hipotesis didapatkan hubungan yang signifikan antara durasi olahraga dengan durasi penggunaan internet dan tingkat keparahan depresi pada mahasiswa UIN Syarif Hidayatullah Jakarta, dimana semakin kurang durasi olahraga dalam seminggu pada mahasiswa, maka akan semakin bertambah durasi penggunaan internet dalam sehari dan semakin berat tingkat keparahan depresinya, serta semakin lama durasi penggunaan internet dalam sehari pada mahasiswa, maka akan semakin berat tingkat keparahan depresinya.

Oleh karena itu diperlukan perhatian khusus kepada mahasiswa dengan durasi olahraga yang kurang agar memiliki kebiasaan olahraga secara rutin untuk meningkatkan kualitas hidupnya, serta mencegah penggunaan internet secara berlebihan dan gejala depresi yang dirasakan oleh mahasiswa. 
Berdasarkan Physical Activity Guidelines for Americans, second editions, rekomendasi durasi olahraga yang cukup dalam seminggu adalah 1,25 - 2,5 jam, dimana durasi lebih dari 2,5 jam masuk ke dalam kategori berlebihan. Olahraga yang berlebihan ini mungkin dapat menimbulkan dampak negatif, hal ini menyebabkan terdapat kemungkinan hubungan yang tidak linear dari variabel durasi olahraga.

Oleh karena itu saran untuk penelitian selanjutnya untuk menganalisis data durasi olahraga sebagai data non-linear, sehingga dapat dianalisis lebih cermat lagi terkait hubungan variabel dengan variabel lainnya.

\section{UCAPAN TERIMA KASIH}

Peneliti mengucapkan terimakasih secara khusus kepada dr. Marita Fadhilah, Dr.Med.Sc dan dr. Bisatyo Mardjikoen, Sp.OT yang telah memberikan banyak masukan pada penelitian ini. Terima kasih juga yang sebesar besarnya kepada pihak UIN Syarif Hidayatullah Jakarta yang telah menyediakan tempat dan fasilitas, serta kepada semua pihak yang telah membantu dalam penelitian ini.

\section{DAFTAR PUSTAKA}

1. Physical Activity [Internet]. World Health Organization. 2020 [cited 15 May 2020]. Available from: https://www.who.int/dietphysicalactivity/pa len/.

2. Riset Kesehatan Dasar 2013. Jakarta: Badan Penelitian dan Pengembangan Kesehatan Kementerian Kesehatan RI Tahun 2013; 2013.

3. Laporan Nasional Riskesdas 2018. Jakarta: Badan Penelitian dan Pengembangan Kesehatan Kementerian Kesehatan; 2019.

4. B. Schuch F, Stubbs B. Physical Activity, Physical Fitness, and Depression. Oxford Research Encyclopedia of Psychology [Internet]. 2017; Available from: https://www.researchgate.net/publication/32 6718821_Physical_Activity_Physical_Fitne ss and Depression.

5. Cicek G, Atan T, Kamuk Y, Imamoglu O, Yamaner F, Aslan V. Effects of Exercise on
Levels of Depression. The Anthropologist. 2015;20(3):670-674.

6. George L. The Relation between Physical Activity and the use of Internet in Schoolchildren. 2016;3(11).

7. Infografis Penetrasi \& Perilaku Pengguna Internet Indonesia Survey 2017 [Internet]. Web.kominfo.go.id. 2017 [cited 4 July 2020]. Available from: https://web.kominfo.go.id/sites/default/files /Laporan\%20Survei\%20APJII_2017_v1.3.p df.

8. Masih J, Rajkumar R. Internet Addiction Disorder and Mental Health in Adolescents. Journal of Depression and Anxiety [Internet]. 2019; Available from: https://www.longdom.org/openaccess/internet-addiction-disorder-andmental-health-in-adolescents.pdf.

9. Test Review: Patient Health Questionnaire9 (PHQ-9). Rehabilitation Counseling Bulletin. 2014;57(4):246-248.

10. U.S. Department of Health and Human Services. Physical Activity Guidelines for Americans, 2nd ed. Washington, DC: U.S. Department of Health and Human Services; 2018.

11. Long-term benefits of regular exercise YMCA of the North [Internet]. YMCA of the North. 2021 [cited 26 September 2021]. Available from: https://www.ymcanorth.org/blog/2017/04/0 4/5991/long_term_benefits_of_regular_exer cise.

12. Wahyudi R, Bebasari E, Nazriati E. Hubungan Kebiasaan Berolahraga dengan Tingkat Stres pada Mahasiswa Fakultas Kedokteran Universitas Riau Tahun Pertama. JOM FK. 2015;2(2).

13. El Ansari W, Khalil K, Crone D, Stock C. Physical Activity and Gender Differences: Correlates of Compliance with Recommended Levels of Five Forms of Physical Activity among Students at Nine Universities in Libya. Central European Journal of Public Health. 2014;22(2):98105.

14. Luzak A, Heier M, Thorand B, Laxy M, Nowak D, Peters A et al. Physical activity levels, duration pattern and adherence to 
WHO recommendations in German adults. PLOS ONE. 2017;12(2):e0172503.

15. Diagnostic and statistical manual of mental disorders. 5th ed. Washington, DC: American Psychiatric Association; 2013.

16. Rabadi L, Ajlouni M, Masannat S, Bataineh $S$, Batarseh $G$ et al. The Relationship between Depression and Internet Addiction among University Students in Jordan. $J$ Addict Res Ther. 2017;8:349.

17. Kannan B, Karthik S, Pal G, Menon V. Gender Variation in the Prevalence of Internet Addiction and Impact of Internet Addiction on Reaction Time and Heart Rate Variability in Medical College Students. Journal of Clinical and Diagnostic Research. 2019;13(4):CC01-CC04.

18. Vyjayanthi S, Makharam S, Afraz $M$, Gajrekar S. Gender Differences in The Prevalence and Features of Internet Addiction among Indian College Students [Internet]. Medica Innovatica. 2014; Available from: https://pdfs.semanticscholar.org/5a9b/fe2e8 0b630c05c7e0e68802df901d9b97a31.pdf.

19. Dufour $M$ et al. Gender Difference in Internet Use and Internet Problems among Quebec High School Students. The Canadian Journal of Psychiatry. 2016;61(10):663-668.

20. The Patient Health Questionnaire (PHQ-9)

- Overview [Internet]. Drugsandalcohol.ie. 2020 [cited 2 July 2020]. Available from: https://www.drugsandalcohol.ie/26814/1/Pa tient\%20Health\%20Questionnaire.pdf.

21. Peltzer K, Pengpid S, Olowu S, Olasupo M. Depression and Associated Factors Among University Students in Western Nigeria. Journal of Psychology in Africa. 2013;23(3):459-465.

22. Sarokhani D, Delpisheh A, Veisani Y, Sarokhani M, Manesh R, Sayehmiri K. Prevalence of Depression among University Students: A Systematic Review and MetaAnalysis Study. Depression Research and Treatment. 2013;2013:1-7.

23. Pearson C, Janz T, Ali J. Mental and substance use disorders in Canada [Internet]. Www150.statcan.gc.ca. 2013 [cited 26 September 2021]. Available from: https://www150.statcan.gc.ca/n1/pub/82624-x/2013001/article/11855-eng.htm.

24. Flesch B, Houvèssou G, Munhoz T, Fassa A. Major depressive episode among university students in Southern Brazil. Revista de Saúde Pública. 2020;54:2.

25. Koçak Ç. How does regular exercise affect internet addiction level in university students?. Physical education of students. 2019;23(4):186-190.

26. Sahin M, Lok S. Relationship between Physical Activity Levels and Internet Addiction of Adults. Journal of Depression and Anxiety. 2018;07(02).

27. Belvederi Murri M, Ekkekakis P, Magagnoli M, Zampogna D, Cattedra S, Capobianco L et al. Physical Exercise in Major Depression: Reducing the Mortality Gap While Improving Clinical Outcomes. Frontiers in Psychiatry. 2019;9.

28. Orsal O, Orsal O, Unsal A, Ozalp S. Evaluation of Internet Addiction and Depression among University Students. Procedia - Social and Behavioral Sciences. 2013;82:445-454. 